\title{
Documentary Analysis of Cases of Sexual Violence Against Boys Reported in Porto Alegre ${ }^{1}$
}

\author{
Jean Von Hohendorff ${ }^{2}$ \\ Universidade Federal do Rio Grande \\ do Sul, Porto Alegre-RS, Brazil \\ Luísa Fernanda Habigzang \\ Pontifícia Universidade Católica do Rio \\ Grande do Sul, Porto Alegre-RS, Brazil
}

\author{
Lucas Souza Costa \\ Pontificia Universidade Católica do Rio \\ Grande do Sul, Porto Alegre-RS, Brazil \\ Silvia Helena Koller \\ Universidade Federal do Rio Grande \\ do Sul, Porto Alegre-RS, Brazil
}

\begin{abstract}
There are few studies regarding sexual violence (SV) against boys in Brazil. Considering this fact, the present study aimed to investigate cases reported in the General Coordination of Health Surveillance of Porto Alegre (POA GVCS) between 2009 and 2011. A total of 239 notification forms were analyzed according to: characteristics of the victim (i.e., age, race, education level, presence of disability, SV consequences); of the SV (i.e., occurrence year, notification year, notifying establishment, context, place of occurrence, type, occurrence of penetration, number of episodes, others forms of violence, number of perpetrators, final classification - whether confirmed or not - and referrals); and of the abusers (i.e., gender, relationship to the victim, use of alcohol/drugs). There was predominance of white boys between seven and 12 years of age, victims of intrafamilial SV of two or more episodes perpetrated by male perpetrators. These results can be used in planning preventive and therapeutic interventions specific to boys who are victims of SV.
\end{abstract}

Keywords: sexual abuse, violence in children, epidemiology

\section{Análise Documental de Casos de Violência Sexual Contra Meninos Notificados em Porto Alegre}

\begin{abstract}
Resumo: A violência sexual (VS) contra meninos é um tema sobre o qual há poucas pesquisas no Brasil. Diante disto, objetivouse investigar os casos notificados na Coordenadoria Geral de Vigilância em Saúde de Porto Alegre (CGSV POA) entre 2009 e 2011. Foram analisadas descritivamente 239 fichas quanto a: características das vítimas (i.e, idade, cor, escolaridade, deficiência, consequências da VS); da VS (i.e., ano de ocorrência e de notificação, estabelecimento notificador, âmbito, local de ocorrência, tipo de VS, ocorrência de penetração, número de episódios, outras formas de violência, número de agressores, classificação final - confirmado ou não - e encaminhamentos); e dos agressores (i.e., sexo, relação com a vítima, uso de álcool/drogas). Houve predominância de meninos entre sete e 12 anos, brancos, vítimas de SV intrafamiliar em dois ou mais episódios, perpetrada por agressores do sexo masculino. Tais resultados podem ser utilizados no planejamento de intervenções preventivas e terapêuticas específicas para meninos vítimas de VS.
\end{abstract}

Palavras-chave: abuso sexual, violência na criança, epidemiologia

\section{Análisis Documental de los Casos de Violencia Sexual Contra Niños Notificados en Porto Alegre}

\begin{abstract}
Resumen: Hay poca investigación en Brasil sobre la violencia sexual (VS) contra los niños. Así, fueron investigados los casos notificados en la Coordinadora General de Vigilancia en Salud de Porto Alegre (CGSV POA) entre 2009 y 2011. Fueron analizadas descriptivamente 239 historias respecto a: características de las víctimas (i.e., edad, color, escolaridad, deficiencias y consecuencias de la VS); de la VS (i.e., año de la ocurrencia y notificación, establecimiento notificador, ámbito, local de ocurrencia, tipo, ocurrencia de penetración, número de episodios, otras formas de violencia, número de agresores, clasificación final - confirmado o no - y direccionamientos); y de los agresores (i.e., sexo, relación con la víctima, uso de alcohol/drogas). Predominaron niños entre siete y 12 años, blancos, víctimas de VS intrafamiliar en dos o más episodios, perpetrada por agresores del sexo masculino. Tales resultados pueden ser utilizados en la planificación de intervenciones preventivas y terapéuticas para niños víctimas de VS.
\end{abstract}

Palabras clave: abuso sexual, violencia en niño, epidemiología

\footnotetext{
1 Acknowledgments: The authors would like to thank the health surveillance general coordinator of Porto Alegre, especially Karla Lindorfer Livi, for the partnership in the data collection and collaboration in improving this article.

2 Correspondence address:

Jean Von Hohendorff. Instituto de Psicologia. Universidade Federal do Rio Grande do Sul. Rua Ramiro Barcelos, 2600, sala 104. CEP 90035-003. Porto Alegre-RS, Brazil. E-mail: jhohendorff@gmail.com
}

Sexual violence (SV) is defined by the Ministry of Health (2002) as all and any act or sexual game, in which the abusers are in a later stage of psychosexual development than the child or adolescent. It can vary from acts in which there is no physical contact (e.g., voyeurism, exhibitionism, 
production of photos) to actions that include physical contact with or without penetration imposed on the children or adolescents due to physical violence, threats, or inducement. It also includes situations of sexual abuse for profit, such as sexual exploitation and exposure to pornography.

Accurate epidemiological data regarding SV are difficult to obtain due to the scenario of underreporting of this type of violence. The available data are primarily based on notifications and do not cover all instances of SV, since there are cases that are not reported. In Brazil, epidemiological data on SV against children and adolescents indicate the predominance of notifications of cases involving girls. A recent report from the Disque Denúncia Nacional (National Program to Combat Sexual Violence against Children and Adolescents, 2011), with data gathered from across the country covering the period between January and February 2011, reported that 11,077 notifications of SV, neglect, and physical and psychological violence were received in which the gender of the victims was reported. The percentage that most differed between the male and female victims was the SV index, with $22 \%$ for males and $78 \%$ for females. Among the specific types of SV, the indices for girls and boys in cases of sexual exploitation, trafficking of children and adolescents, and sexual abuse were respectively $80 \%$ and $20 \%, 67 \%$ and $33 \%$, and $77 \%$ and $23 \%$.

In a literature review study (Hohendorff, Habigzang, \& Koller, 2012), 11 Brazilian studies were included covering the southern, southeastern and northern regions of Brazil which described epidemiological data from child and adolescent victims of SV. In all the studies, the indices of SV against boys were lower than the indices of SV against girls. Clinical populations were the target of ten studies, in which there was a predominance of female victims, with indices between $64.2 \%$ and $91.5 \%$, compared to cases against boys. Only one study (Polanczyk, Zavaschi, Benetti, Zenker, \& Gammerman, 2003) investigated SV in the general population, with the difference between girls and boys being lower. Among 1193 adolescents between 13 and 20 years of age 27 were victims of sexual violence, $40.7 \%$ boys and $59.3 \%$ girls.

Although the number of studies on SV against children has evolved considerably in recent decades, primarily due to increased social attention regarding the phenomenon, the target of these studies is usually female victims preventing the generalization of the results for male victims (MaikovichFong \& Jaffee, 2010). This scenario encompasses national and international studies, although outside Brazil there are a greater number of publications on SV against boys. Brazilian studies describing the characteristics of the victims and abusers in cases of SV against boys available in databases are scarce. Only one article was found (Hohendorff et al., 2012), this being a literature review covering international studies to describe the characteristics of the victims, offenders, and the SV. However, there are other types of publications (i.e., dissertations, theses, books) in which such characteristics are described (Kristensen, 1996; Pinto Junior, 2005; Pires
Filho, 2009; Prado, 2006). Taken together, the results of the Brazilian publications indicate the predominance of cases of sexual violence in childhood (zero to 12) occurring in contexts of families with socioeconomic difficulties and perpetrated by male abusers (Kristensen, 1996; Pinto Junior, 2005; Pires Filho, 2009; Prado, 2006). However, caution is needed when analyzing these results, given that their goals were not to describe the characteristics of the victims, abusers and the SV. For example, the larger number of intrafamilial abusers may be due to the aim of investigating intrafamilial SV in two studies consulted (Pires Filho, 2009; Prado, 2006). Furthermore, there was one study that investigated the perception of clinical psychologists in care institutions of sexual violence victims (Pires Filho, 2009), without consulting medical records or other documents that could objectively verify the information reported.

Internationally, the number of studies on male victims of $\mathrm{SV}$ is higher, however, still incipient compared to the number of studies on female victims. This scenario can be explained by factors such as finding that male victims do not disclose or have greater difficulty revealing SV and that professionals fail to suspect or investigate the possible occurrence of SV in boys and men (Holmes \& Offen, 1997). Although fewer in number, studies with male victims, mainly adults with a history of SV in childhood, indicate that the difficulty for boys to reveal SV (Alaggia, 2005; Sorsoli, Kia-Keating, \& Grossman, 2008) leads to consequences such as somatization, obsessive-compulsive symptoms, depression, anxiety and hostility, interpersonal difficulties, phobic anxiety, paranoid ideation and psychosis (Collings, 1995), stress (Steever, Follete, \& Naugle, 2001), emotional problems (e.g., anger, helplessness and shame), cognitive distortions (e.g., selfblame and inability to consider their experience as violence), interpersonal difficulties (e.g., sense of betrayal, isolation) and problems related to sexuality and sexual orientation, which were more frequent in victims sexually violated by men (Lisak, 1994). Reviews of the international literature have corroborated these results (Romano \& De Luca, 2001) and reported the characteristics of the victims, abusers and the SV itself (Holmes \& Slap, 1998).

The analysis of 166 studies published between 1985 and 1997 in the English language, with the minimum participation of 20 North-American boys aged 19 years and victims of $\mathrm{SV}$, indicated that the mean age at the occurrence of the SV was 9.8 years, with a median of 10 years and $58 \%$ under 11 years of age (Holmes \& Slap, 1998). The victim profile most found was of boys who: reside with the mother only or with neither parent; have remarried or separated parents who abuse alcohol or engage in criminal behavior; have black or brown skin color; and belong to the lower levels of the social strata. The situations of violence were perpetrated mostly by men (53\% to $94 \%)$. The majority of the situations of SV were a single episode (46\% to $93 \%$ of the cases). However, $17 \%$ to $53 \%$ of the participants in the studies reviewed were victims of chronic cases lasting 
between six and 48 months. Three forms of SV were more frequently described: anal penetration by the victim or by the abuser, vaginal penetration by the abuser, and oral sex by the victim on his/her abuser or vice versa. The presence of physical violence, concomitant with the SV, was common, obtaining indices from $36 \%$ to $68 \%$ of the cases. Finally, the analyzed results indicated that boys under six years of age are more exposed to intrafamilial SV, while there is increased risk of extrafamilial sexual violence for those above 12 years of age (Holmes \& Slap, 1998).

Considering the lack of studies on the characteristics of the victims, offenders, and the SV perpetrated against boys, as well as the importance of this information for the improvement and formulation of public policies, the aim of this study was to investigate cases of sexual violence against boys between zero and 18 years of age, reported in the Violence and Accidents Surveillance System (VIVA) of the Health Surveillance General Coordinator of Porto Alegre (CGSV POA) between the years 2009 and 2011. Specifically, the aim was to identify the characteristics of the victims, abusers, and the SV.

\section{Method}

A descriptive documentary study was carried out using the domestic, sexual and/or other violence notification forms of the Violence and Accident Surveillance (VIVA) - Notifiable Injuries Report System (SINAN/Ministry of Health), of Porto Alegre. The management of VIVA in Porto Alegre is conducted by the Health Surveillance General Coordinator (CGSV), of the Municipal Health Secretariat, where the data were collected. The CGSV has received notifications of violence, including sexual violence, from the protection and care services throughout the municipality since 2009 using SINAN.

\section{Sample}

The notification forms of violence relating to suspected and/or confirmed cases of SV against boys aged zero to 18 years, reported in the years 2009, 2010 and 2011 were selected. This period was chosen in order to obtain current data and to use only the SINAN notifications, aiming for homogeneity of the data collected. The selection resulted in $239(11.13 \%)$ records of cases of SV against boys among a total of 2147 records of cases of SV against children reported in the CGSV. The data were then collected using a data registration protocol.

\section{Instruments}

Data registration protocol. This instrument was developed for this study from the information contained in the violence notification form, from which information was collected about the victims (i.e., age, skin color, schooling, presence of disabilities, consequences of the SV), about the
SV (i.e., year of occurrence, year of notification, notifying establishment, context, place of occurrence, type of SV, occurrence of penetration, number of episodes, presence of other forms of violence, number of abusers, final classification - whether confirmed or not, and referrals), and about the abusers (i.e., gender, relationship with the victim, use of alcohol/drugs).

\section{Procedure}

Data collection. The violence notification forms were filled in by professionals (e.g., psychologists, social workers, physicians, nurses) responsible for the care in the services in which the reports were made. The data were collected as indicated in the forms that were completed by the professionals when the cases were being reported. These forms remained stored in the CGSV archives. Initially, the notifications forms of occurrences between 2009 and 2011 were selected. Each of the forms was then verified in order to select only the cases of SV against boys. A copy of the data registration protocol was used to collect the data from each selected form.

Data analysis. The collected data were tabulated in a database using the Statistical Package for the Social Sciences (SPSS, version 19). All the variables were analyzed descriptively obtaining absolute values and frequencies.

\section{Ethical Considerations}

This study was approved by the research ethics committees of the Instituto de Psicologia of the Universidade Federal do Rio Grande do Sul and of the Municipal Health Secretariat of Porto Alegre with the numbers 20318 and 001.028725.11.5, respectively. All the resolutions in force regarding research ethics were observed during the performance of the study.

\section{Results}

Between 2009 and 2011 records of 239 forms related to cases of sexual violence against boys aged zero to 18 years were identified. Information regarding the characteristics of the victims, the abusers, and the SV was collected from these forms. The total number of forms analyzed for each characteristic varied due to the absence of some information in these records, as well as due to the fact that sometimes the same form contained more than one option checked for each variable analyzed. The total amount of information analyzed according to each characteristic is shown in Tables 1, 2 and 3.

Regarding the characteristics of the victims (Table 1), the cases were of boys between two and 18 years of age at the time of the notification. The ages of the victims were divided into three age groups for the data analysis, the most frequent of the those being the seven to 12 year old group (55.2\%), followed by two to six years $(26.4 \%)$ and 13 to18 years $(17.1 \%)$. The predominant skin color was white $(70 \%)$, followed by black 
(16.6\%) and brown (14.4\%). Regarding schooling, there was a predominance of boys with incomplete first to fourth grades (65.1\%), followed by no schooling (14.9\%), incomplete fifth to eighth grades $(10.8 \%)$, complete fourth grade $(6.7 \%)$, complete elementary education (1.5\%) and incomplete high school education (1.0\%). The majority of the boys $(89.2 \%)$ had no disabilities (i.e., physical disability, mental impairment, visual impairment, hearing impairment, mental disorder, behavioral disorders, or other disabilities/syndromes). In 61 cases some consequences of the SV for the victims were reported. The most frequent consequences were behavioral disorders (41\%) and posttraumatic stress disorder (PTSD; 41\%), followed by Sexually Transmitted Diseases (STD, 11.4\%), mental disorders (3.3\%), and others (i.e., physical injuries and overall developmental disorder - 3.3\%). The indication of mental and behavioral disorders or PTSD was made only when there was information about the clinical diagnosis by qualified healthcare professional. If the professionals noticed any serious consequence not covered by the options on the form, the option "other" would be checked, followed by the specification of the consequences (Ministry of Health, 2009).

Table 1

Characteristics of the Victims

\begin{tabular}{|c|c|c|}
\hline Variables & $n$ & $\%$ \\
\hline \multicolumn{3}{|l|}{ Age in years $(N=236)$} \\
\hline 2 to 6 & 63 & 26.4 \\
\hline 7 to 12 & 132 & 55.2 \\
\hline 13 to 18 & 41 & 17.1 \\
\hline \multicolumn{3}{|l|}{ Skin color $(N=235)$} \\
\hline White & 162 & 70 \\
\hline Brown & 34 & 14.4 \\
\hline Black & 39 & 16.6 \\
\hline \multicolumn{3}{|l|}{ Schooling $(N=195)$} \\
\hline None & 29 & 14.9 \\
\hline Incomplete 1 st to 4 th grade & 127 & 65.1 \\
\hline Complete 4 th grade & 13 & 6.7 \\
\hline Incomplete 5 th to 8 th grade & 21 & 10.8 \\
\hline Complete elementary education & 3 & 1.5 \\
\hline Incomplete high school education & 2 & 1.0 \\
\hline \multicolumn{3}{|l|}{ Disability of the victim $(N=232)$} \\
\hline Yes & 25 & 10.8 \\
\hline No & 207 & 89.2 \\
\hline \multicolumn{3}{|l|}{ Consequences $(N=61)$} \\
\hline Behavioral Disorder & 25 & 41 \\
\hline PTSD & 25 & 41 \\
\hline STD & 7 & 11.4 \\
\hline Mental Disorder & 2 & 3.3 \\
\hline Other & 2 & 3.3 \\
\hline
\end{tabular}

The analysis of the characteristics of the SV (Table 2) indicated that the majority of cases occurred within the period between 2008 and 2011 (98.3\%), divided into two groups (i.e., 2002 to 2007 and 2008 to 2011) due to the low frequency of cases between 2002 and 2007. Although cases have occurred since the year 2002, notification occurred only during the three years analyzed, with similar percentages - 2009 (30.1\%), 2010 (31\%) and 2011 (38.9\%). The most frequent notifying establishments were the specialized violence care services (i.e., the Child Protection Service and Child and Adolescent Referral Center [CRAI] of the President Vargas Mother and Child Hospital [HMIPV] - 96.7\%).

The SV occurred more frequently in the intrafamilial context $(57.9 \%)$ than in the extrafamilial $(41.3 \%)$, with the intrafamilial context considered when the $\mathrm{SV}$ was perpetrated by one or more abusers with blood or affinity ties with the victims (Ministry of Health, 2009). The SV occurred in both contexts in only $0.4 \%$ (1) of the cases. The most frequent site of occurrence was the residence of the victim (78.7\%), followed by collective dwelling (e.g., institutional care unit; $6.5 \%$ ), public streets $(5.7 \%)$, school $(5.2 \%)$ and others (i.e., not included in previous categories, such as lakes, abandoned houses (Ministry of Health, 2009), etc. - 3.9\%).

The most frequent types of SV were rape $(80.7 \%)$, understood as that defined by Article 213 of Law number $12.015 / 2009$ and indecent assault $(16 \%)$ as defined by Decree-law 2.848/1940, which was replaced by Law number $12.015 / 2009$ with respect to SV crimes. The crime of indecent assault consisted, until the change in the law made in 2009, of compelling someone through violence or serious threats to perform diverse, lewd acts of a sexual nature or to allow these acts to be performed on them. With the alteration, the characterization of indecent assault was abolished and all crimes against the sexual dignity became typified as rape to compel someone, through violence or serious threat, to have sexual intercourse or to perform or allow the practice of other lewd acts.

Other forms of SV present were: (a) sexual harassment (8.8\%), i.e., the act of embarrassing someone with questions, proposals and claims of a sexual nature (Ministry of Health, 2009); (b) child pornography (2.5\%), understood as the presentation, production, sale, supply, distribution and/or publication of photographs or images containing pornography or explicit sex scenes involving children and adolescents (Ministry of Health, 2009); and (c) sexual exploitation $(0.4 \%)$, understood as the use of people for commercial purposes and profit for the practice of sexual acts (Ministry of Health, 2009). Penetration was present in 130 cases, with the majority oral $(67.7 \%)$ and the remainder classed as anal (32.3\%).

The majority of cases of SV consisted of two or more episodes $(72.2 \%)$ compared to situations of a single episode $(27.8 \%)$. Other forms of violence were present, with the most frequent being psychological/moral (i.e., rejection, depreciation, discrimination, disrespect, excessive demands, humiliating punishments, and the use of the person to meet the psychological needs of others 
[Ministry of Health, 2009] - 67.9\%). Physical violence (i.e., violent acts with the intentional use of physical force with the aim of hurting, harming, causing pain and suffering, or destroying the victim [Ministry of Health, 2009]) was the second most frequent form of violence $(27.9 \%)$, followed by other forms (i.e., not covered by the above categories [Ministry of Health, 2009], such as kidnapping - 4.2\%). The predominant number of abusers was one $(84.5 \%)$, and in $15.5 \%$ of the cases there were two or more abusers.

The final classification of the majority of cases was 'likely' (87.2\%), followed by 'confirmed' (12.3\%) and 'inconclusive' $(0.4 \%)$ according to information contained in the forms used. The final classification of 'confirmed' was when the victim presented evidence (signs, symptoms, or past history) of having been the target of at least one violent act, regardless of the existence of suspicions of having been the victim of other types of violence (Ministry of Health, 2009). Classifications of 'likely' occurred when the person attended/victim presented indications (less than evidence) of violence, whether or not presenting signs, symptoms and a history of violence (Ministry of Health, 2009). Finally, inconclusive cases, according to the guidelines for filling in the form, should not occur in situations of violence due to the characteristics of these events (Ministry of Health, 2009).

The referral most frequently adopted was to the legal services (i.e., police stations, child and youth shelters, Public Prosecution Service and Medical-Legal Institute - 51\%). Other referrals made were to the: (a) Guardianship Council (40\%), (b) care services (i.e., Social Assistance Reference Centers [CRAS], Specialized Social Assistance Reference Centers [CREAS], Sentinela project - 7.7\%), and (c) institutional care units $(1.3 \%)$. The same case could have more than one referral.

Regarding the characteristics of abusers (Table 3), the majority (93.4\%) were male, with only $3 \%$ females. In $3.4 \%$ of cases the abusers were of both sexes. The analysis of the relationship between the abusers and victims indicated variability. Friend/acquaintance was the most frequent relationship (28.7\%), followed by others (23.9\%), father $(16.6 \%)$, stepfather $(9.3 \%)$, uncle $(8.5 \%)$, cousin $(6.9 \%)$, and brother $(6.0 \%)$. The relationships included in the category "others" were: teachers, strangers, mother, and stepmother) which showed frequencies lower than $5 \%$. Finally, the majority $(60.1 \%)$ of the abusers presented no suspicion of drug use.

\section{Discussion}

The most frequent profile of the victims was of boys between seven and 12 years at the time of notification, white, with schooling between incomplete first and fourth grades. This profile is consistent with studies conducted in Brazil (Hohendorff et al., 2012; Kristensen, 1996; Pinto Junior, 2005; Pires Filho, 2009; Prado, 2006), although the majority did not investigate the profile of the victims (Kristensen, 1996; Pinto Junior, 2005; Pires Filho, 2009; Prado, 2006). Internationally, the age as described in a review of studies
Table 2

Characteristics of the Sexual Violence

\begin{tabular}{|c|c|c|}
\hline Variables & $n$ & $\%$ \\
\hline \multicolumn{3}{|l|}{ Year of occurrence $^{\mathrm{a}}(N=239)$} \\
\hline 2002 to 2007 & 4 & 1.7 \\
\hline 2008 to 2011 & 235 & 98.3 \\
\hline \multicolumn{3}{|l|}{ Year of notification $(N=239)$} \\
\hline 2009 & 72 & 30.1 \\
\hline 2010 & 74 & 31.0 \\
\hline 2011 & 93 & 38.9 \\
\hline \multicolumn{3}{|l|}{ Notifying establishment $(N=239)$} \\
\hline Specialized violence care service & 231 & 96.7 \\
\hline Non-specialized services & 8 & 3.3 \\
\hline \multicolumn{3}{|l|}{ Context $(N=235)$} \\
\hline Intrafamilial & 136 & 57.9 \\
\hline Extrafamilial & 97 & 41.3 \\
\hline Both & 1 & 0.4 \\
\hline \multicolumn{3}{|l|}{ Place of occurrence $(N=230)$} \\
\hline Residence & 181 & 78.7 \\
\hline Collective dwelling & 15 & 6.5 \\
\hline Public street & 13 & 5.7 \\
\hline School & 12 & 5.2 \\
\hline Other & 9 & 3.9 \\
\hline \multicolumn{3}{|l|}{ Type of sexual violence $(N=238)$} \\
\hline Rape & 192 & 80.7 \\
\hline Indecent Assault & 38 & 16 \\
\hline Sexual Harassment & 21 & 8.8 \\
\hline Child Pornography & 6 & 2.5 \\
\hline Sexual Exploitation & 1 & 0.4 \\
\hline \multicolumn{3}{|l|}{ Penetration $(N=130)$} \\
\hline Oral & 88 & 67.7 \\
\hline Anal & 42 & 32.3 \\
\hline \multicolumn{3}{|l|}{ Number of episodes $(N=180)$} \\
\hline Two or more & 130 & 72.2 \\
\hline One & 50 & 27.8 \\
\hline \multicolumn{3}{|l|}{ Other forms of violence $(N=190)$} \\
\hline Psychological/Moral & 129 & 67.9 \\
\hline Physical & 53 & 27.9 \\
\hline Other & 8 & 4.2 \\
\hline \multicolumn{3}{|l|}{ Number of abusers $(N=233)$} \\
\hline One & 197 & 84.5 \\
\hline Two or more & 36 & 15.5 \\
\hline \multicolumn{3}{|l|}{ Final classification $(N=235)$} \\
\hline Likely & 205 & 87.2 \\
\hline Confirmed & 29 & 12.3 \\
\hline Inconclusive & 1 & 0.4 \\
\hline \multicolumn{3}{|l|}{$\operatorname{Referrals}^{\mathrm{b}}(N=557)$} \\
\hline Justice services & 284 & 51 \\
\hline Guardianship Council & 222 & 40 \\
\hline Care services & 43 & 7.7 \\
\hline Institutional care unit & 8 & 1.3 \\
\hline
\end{tabular}

Note. a Grouped into two groups due to the low frequency of cases between 2002 and 2007. brouped into categories due to the large number of services. 
Table 3

\begin{tabular}{lcc} 
Characteristics of the Abusers & & \\
\hline Variables & $n$ & $\%$ \\
\hline Gender of Abuser $(N=235)$ & 220 & 93.4 \\
$\quad$ Male & 7 & 3.0 \\
Female & 8 & 3.4 \\
Both & & \\
Relationship with victim $(N=247)$ & 71 & 28.7 \\
Friend/acquaintance & 41 & 16.6 \\
Father & 23 & 9.3 \\
Stepfather & 21 & 8.5 \\
Uncle & 17 & 6.9 \\
Cousin & 15 & 6.0 \\
Brother & 59 & 23.9 \\
Other & & \\
Suspected drug use $(N=163)$ & 98 & 60.1 \\
$\quad$ No & 65 & 39.9 \\
$\quad$ Yes &
\end{tabular}

in English was similar (mean of 9.8 years), while the predominant skin colors were black or brown (Holmes \& Slap, 1998). The predominance of white skin color in the reported cases of sexual violence against boys may be linked to the predominance of individuals of this skin color in the population of Porto Alegre (79.2\%) and Rio Grande do Sul (83\% - Porto Alegre City Observatory 2011).

The analysis of the profile of the victims also indicated a low frequency of disabled children (i.e., physical disability, mental impairment, visual impairment, hearing impairment, mental disorder, behavioral disorders and other disabilities/ syndromes). Of the cases that contained this information, the presence of a disability was observed in only $25(10.8 \%)$. This result could initially indicate a lower frequency of sexual violence against disabled boys. However, people with disabilities are considered as a group at increased risk for sexual violence (Tobin \& Kessner, 2002). Furthermore, people with disabilities may have more difficulty in making the revelation due to the characteristics of the disability itself (e.g., communicative, cognitive). Thus, the low frequency of child victims of sexual violence with disabilities found in this study may indicate a scenario of greater underreporting of SV in this particular group.

The SV occurred more often in an intrafamilial context, perpetrated by male abusers in two or more episodes, with the place of the occurrence being the residence of the victim, and with the presence of psychological or moral violence. These characteristics are consistent with previous studies (Kristensen, 1996; Pinto Junior, 2005; Pires Filho, 2009; Prado, 2006), as well as with the dynamics of SV against children and adolescents (Furniss, 1993; Sgroi, Blick, \& Porter, 1982; Spiegel, 2003; Summit, 1983), although the majority of studies are based on cases involving girls. This shows possible patterns in the cases of SV against children and adolescents regardless of the gender of the victims.
The study of the dynamics of SV against children and adolescents indicates the initiation of SV through actions of the abusers, generally known by the victims, in order to gain their trust. When the trust is obtained, the sexual interactions tend to be initiated in more subtle ways (e.g., touching, caressing), progressing to more intimate forms (e.g., oral sex, penetration). The occurrence of multiple episodes of SV is explained by the Addition Syndrome (Furniss, 1993) on behalf of the abusers. Most often, they know that the SV is something wrong and that it constitutes a crime as well as being detrimental to the victims, however, faced with the stimulus (i.e., the victim) they present a lack of impulse control and continue committing the SV. This syndrome resembles the process of substance addiction.

When the victims realize the inappropriate nature of the interactions, they seek to reveal what has taken place, however, mainly due to the shame they feel and the various threats (i.e., psychological violence) that the offenders make, they keep it secret (Sgroi et al., 1982). In addition to the shame and threats the SV can be kept secret through bargaining and blackmail used by the abusers, which creates the perception in the victims that they were to blame for the occurrence of the SV or for not revealing it. The combination of these elements (i.e., the presence of threats, bargaining, guilt and shame), often combined with the account of the victims being discredited is known as the Syndrome of Secrecy (Furniss, 1993), which is related to the Accommodation Syndrome (Summit, 1983). The victims feel helpless, unable to count on the help of other adults and they "accommodate" the situation due to not finding another way out and in order to maintain the family relationships.

Many victims, however, manage to reveal the SV, at which point there is often pressure for them to retract the allegations (Sgroi et al., 1982). Such pressure may contribute to the SV being continued, although currently a retraction is considered to be another indicative element of the occurrence of SV. The analysis of the years of occurrence of SV and years of its notification highlighted a range from 2002 to 2011 for the occurrence, and 2009 to 2011 for the notification, indicating the possible presence of Syndrome of Secrecy (Furniss, 1993) and Accommodation (Summit, 1983). In addition to the secret that is held by the victims or at a family level, specifically in situations of SV against boys, it is proposed that there is also social invisibility (Spiegel, 2003). The scarcity of social and scientific discussion on the subject would collaborate so that the situations against SV boys are not revealed or reported (Spiegel, 2003).

In more than half of the reported cases, the presence of anal or oral penetration was indicated by the professionals when filling in the forms. While this confirms the occurrence of sexual violence when analyzing the final classification given by the professionals, i.e., whether the reported violence was considered confirmed, likely or inconclusive, there was a classification of likely in $87.2 \%$ of the forms. 
The report of the victims regarding the occurrence of sexual violence is the source of information that the professionals have for filling in the forms. The discrepancy between the presence of penetration and the final classification indicated in the forms suggests that the professionals seem to have difficulty considering the reports of the victims to certify the occurrence of SV at the time of the report. Different factors may contribute to this scenario, including but not limited to: lack of professional training, mainly due to the restricted coverage of the issue of violence in the undergraduate curricula (Gonçalves \& Ferreira, 2002), resulting in confusion regarding the definition, dynamics and consequences of SV; fear, on behalf of the professionals, in relation to the legal ramifications of the notification and possible retaliation from the abusers; misleading perceptions about legal provisions (Gill \& Ferreira, 2002); and the need for material evidence to confirm the SV.

The consequences of SV described in the forms analyzed showed the presence of psychological disorders (e.g., behavioral disorder, posttraumatic stress disorder), and STD. Regarding the psychological consequences, the notification form has the categories 'mental disorder', 'behavioral disorder' and 'posttraumatic stress disorder' even though they overlap according to the American Psychiatric Association (2002).

The instructive for completing the notification form indicates that these categories should be filled in by qualified health professionals (Ministry of Health, 2009), however, it does not stipulate the basis for the diagnosis or for this overlap. Thus, the differences between the categories 'mental disorder', 'behavioral disorder' and 'posttraumatic stress disorder' present in the notification form could be clarified in order to provide more precise information.

The analysis of the referrals made revealed a dismissive attitude regarding the psychological consequences indicated in the notification form, as these were mostly to the justice services and Guardianship Council (GC). Referrals to GC and justice services were also common in the results of previous studies (Habigzang, Azevedo, \& Koller, 2006; Pelisoli, Pires, Almeida, \& Dell'Aglio, 2010). This scenario can be explained, in part, by the lack of public services that provide mental health care, since cases of SV against children are the responsibility of the Public Social Assistance System (SUAS) which provides psychosocial care and not psychotherapy, according to Resolution number 15/2004 of the National Council of Social Welfare. This is an aspect to be discussed and reviewed within the public policies. Psychosocial care does not replace psychotherapy. Considering that SV can generate serious mental health problems, it is indicated that victims receive psychotherapeutic and psychopharmacological care when needed.

\section{Conclusion}

Through the performance of this study it was possible to reveal the characteristics of the victims, the violence and the abusers in the cases of SV against boys reported between 2009 and 2011 in the CGSV of Porto Alegre. In a context of few studies related to SV against boys, the divulgation of information regarding its occurrence, as happens with females, has the potential to promote prevention and intervention strategies focused on boys.

However, the results of this study should be used with caution due to its limitations. Sexual violence against children and adolescents is still an underreported violation of rights. In cases of sexual violence against children, this underreporting may be even higher. The lack of social discussion of these cases, as well as standards of masculinity (e.g., boys and men are strong, invulnerable) that are incompatible with the role of a victim of sexual violence can cause the boys who are victims not to reveal the abuse. The results regarding the characteristics of the victims, the SV and the perpetrators presented in this study may not reflect the full reality of the cases of SV against boys, but only of those reported. This limitation is inherent in descriptive studies of sexual violence, given that the data available for research are from the reported cases.

The forms analyzed were filled in by professionals and their perceptions regarding the report of the victims may have interfered with the completion of the forms. Accordingly, the data listed in the forms and, consequently, the results of this study, may reflect the perception of the professionals regarding sexual violence against boys and not purely the phenomenon itself. In addition, the forms used in the data collection were from suspected and confirmation cases and, due to this, some cases analyzed may not have been from victims. This limitation tends to be common in studies such as this due to the difficulty in finding documents in which there are clear positions on the occurrence or not of SV. Furthermore, the data analyzed in this study have geographical limitations and may not apply to other regions of the country. The period analyzed (i.e., 2009 to 2011) was also limited, offering only a current profile of the cases of SV against children reported in the CGSV of Porto Alegre. Thus, broader studies performed in other regions of the country could be conducted with the aim of deepening the knowledge regarding situations of SV against boys.

Conducting further studies could contribute to the reduction of the phenomenon of social invisibility (Spiegel, 2003) of SV against boys. Greater social visibility of SV against boys can help victims who have difficulty reporting the abuse (Alaggia, 2005; Sorsoli et al., 2008), often because of doubts about their sexual orientation (Lisak, 1994; Romano \& De Luca, 2001), as the SV is usually perpetrated by a male abuser (Hohendorff et al., 2012, Kristensen, 1996; Pinto Junior, 2005; Pires Filho, 2009; Prado, 2006) that can make the boys believe they are homosexual. Prevailing standards of masculinity based on independence and stoicism (Sanderson, 2005) also contribute to the social invisibility of SV. 
Finally, the results regarding the final classification of the notifications indicate the need for professional training for the notifiers. Through professional training related to the definition of SV, its dynamics and consequences, as well as strategies for evaluating cases of SV, professional notifiers could include more precise information on the confirmation of the occurrence of SV.

\section{References}

Alaggia, R. (2005). Discloing the trauma of child sexual abuse: A gender analysis. Journal of Loss and Trauma, 10(5), 453-470. doi:10.1080/15325020500193895

American Psychiatryc Association. (2002). DSM-IV-TR, Manual Diagnóstico e Estatístico de Transtornos Mentais (4th ed. revisada). (C. Dornelles, Trad.). Porto Alegre: Artes Médicas.

Collings, S. J. (1995). The long-term effects of contact and noncontact forms of child sexual abuse in a sample of university men. Child Abuse \& Neglect, 19(1), 1-6. doi:10.1016/0145-2134(94)00098-F

Decreto-lei $\mathrm{n}^{\circ}$ 2.848, de 7 de dezembro de 1940 (1940, 31 de dezembro). Institui o Código Penal. Diário Oficial da República do Brasil, Poder Executivo.

Furniss, T. (1993). Abuso sexual da criança: Uma abordagem multidisciplinar. (M. A. V. Veronese, Trad.). Porto Alegre: Artes Médicas.

Gonçalves, H. B. \& Ferreira, A. L. (2002). Notificação da violência intrafamiliar contra crianças e adolescentes por profissionais de saúde. Cadernos de Saúde Pública, 18(1),315-319. doi:10.1590/S0102-311X2002000100032

Habigzang, L. F., Azevedo, G. A., Koller, S. H., \& Machado, P. X. (2006). Fatores de risco e de proteção na rede de atendimento a crianças e adolescentes vítimas de violência sexual. Psicologia: Reflexão e Crítica, 19(3), 379-386. doi:10.1590/S0102-79722006000300006

Hohendorff, J. V., Habigzang, L. F., \& Koller, S. H. (2012). Violência sexual contra meninos: Dados epidemiológicos, características e consequências. Psicologia USP, 23(2),395-415. doi:10.1590/S0103-65642012005000007

Holmes, G. R., Offen, L., \& Waller, G. (1997). See no evil, hear no evil, speak no evil: Why do relatively few male victims of childhood sexual abuse receive help for abuserelated issues in adulthood. Clinical Psychology Review, 17(1), 60-88. doi:10.1016/S0272-7358(96)00047-5

Holmes, W. C., \& Slap G. B. (1998). Sexual abuse of boys: Definition, prevalence, correlates, sequelae and management. Journal of American Medical Association, 280(21), 1855-1862. doi:10.1001/jama.280.21.1855

Kristensen, C. H. (1996). Abuso sexual em meninos (Master's thesis, Universidade Federal do Rio Grande do Sul, Porto Alegre-RS, Brazil). Retrieved from http://www. lume.ufrgs.br/bitstream/handle/10183/1432/000177073. pdf?sequence $=1$
Lei $\mathrm{n}^{\mathrm{o}}$ 12.015, de 7 de agosto de 2009 (2009, 10 de agosto). Altera o Título VI da Parte Especial do Decreto-Lei $n^{\circ}$ 2.848, de 7 de dezembro de 1940 - Código Penal, e o art. $1^{\circ}$ da Lei no 8.072, de 25 de julho de 1990, que dispõe sobre os crimes hediondos, nos termos do inciso XLIII do art. $5^{\circ}$ da Constituição Federal e revoga a Lei no 2.252 , de 10 de julho de 1954, que trata de corrupção de menores. Diário Oficial da União. Retrieved from http://www.planalto.gov. br/ccivil_03/_ato2007-2010/2009/lei/112015.htm

Lisak, D. (1994). The psychological impact of sexual abuse: Content analysis of interviews with male survivors. Journal of Traumatic Stress, 7(4), 525-548. doi:10.1002/jts. 2490070403

Maikovich-Fong, A. K., \& Jaffee, S. R. (2010). Sex differences in childhood sexual abuse characteristics and victims' emotional and behavioral problems: Findings from a national sample of youth. Child Abuse \& Neglect, 34(6), 429-437. doi:10.1016/j.chiabu.2009.10.006

Ministério da Saúde (2002). Notificação de maus-tratos contra crianças e adolescentes pelos profissionais de saúde: Um passo a mais na cidadania em saúde. Brasília: Secretaria de Assistência à Saúde. Retrieved from http://bvsms.saude.gov.br/bvs/publicacoes/notificacao_ maustratos_criancas_adolescentes.pdf

Ministério da Saúde (2009). Instrutivo de preenchimento da ficha de notificação/investigação de violência doméstica, sexual elou outras violências. Retrieved from http:// www.dive.sc.gov.br/conteudos/agravos/Dant/Instrutivo_ Violencias.pdf

Pelisoli, C., Pires, J. P. M., Almeida, M. E., \& Dell'Aglio, D. D. (2010). Violência sexual contra crianças e adolescentes: Dados de um serviço de referência. Temas em Psicologia, 18(1), 85-97.

Pinto Junior, A. A. (2005). Violência sexual doméstica contra meninos: Um estudo fenomenológico. São Paulo: Vetor.

Pires Filho, M. F. (2009). Abuso sexual em meninos: A violência intrafamiliar através do olhar de psicólogo que atende em instituições. Curitiba: Juruá.

Polanczyk, G. V., Zavaschi, L., Benetti, S., Zenker, R., \& Gammerman, P. W. (2003). Violência sexual e sua prevalência em adolescentes de Porto Alegre, Brasil. Revista de Saúde Pública, 37(1), 8-14. doi:10.1590/S0034-89102003000100004

Prado, S. F. (2006). Dimensões da violência sexual contra meninos sob a ótica de gênero: Um estudo exploratório (Master's thesis, Universidade de Brasília, Brasília,-DF, Brazil). Retrieved from http://repositorio.bce.unb.br/ bitstream/10482/2302/1/Sonia\%20Fortes\%20do\%20 Prado.pdf

Programa Nacional de Enfrentamento da Violência Sexual Contra Crianças e Adolescentes (2011). Relatório disque direitos humanos - Módulo criança e adolescente. Brasília: Secretaria de Direitos Humanos da Presidência da República. Retrieved from http://portal.mj.gov.br/ sedh/spdca/T/RELATORIO\%202011\%20_agosto_.pdf 
Observatório da Cidade de Porto Alegre (2011). IBGE divulga os números de raça/cor de Porto Alegre. Retrieved from http://www2.portoalegre.rs.gov.br/observatorio/default. php?reg=203\&p_secao $=17$

Resolução $\mathrm{n}^{\mathrm{o}}$ 15, de 15 de outubro de 2004 (2004, 28 de outubro). Aprova a Política Nacional de Assistência Social. Diário Oficial da União, seção 1. Retrieved from http://www.mds.gov.br/acesso-a-informacao/legislacao/ $\mathrm{mds} /$ resolucoes/2004/Resolucao\%20no\%20145-\%20 de\%2015\%20de\%20outubro\%20de\%202004.pdf/view

Romano, E., \& De Luca, R. V. (2001). Male sexual abuse: A review of effects, abuse characteristics, and links with later psychological functioning. Aggression and Violent Behavior, 6(1), 55-78. doi:10.1016/S1359-1789(99)00011-7

Sanderson, C. (2005). Abuso sexual em crianças: Fortalecendo pais e professores para proteger crianças contra abusos sexuais e pedofilia. (F. de Oliveira, Trad). São Paulo: M. Books do Brasil.

Sgroi, S. M., Blick, L. C., \& Porter, F. S. (1982). A conceptual framework for child sexual abuse. In S. M. Sgroi (Ed.), Handbook of clinical intervention in child sexual abuse (pp. 9-37). EUA: The Free Press.

Sorsoli, L., Kia-Keating, M., \& Grossman, F. K. (2008). "I keep that hush-hush": Male survivors of sexual abuse and the challenges of disclosure. Journal of Counseling Psychology, 55(3), 333-345. doi:10.1037/0022-0167.55.3.333

Spiegel, J. (2003). Sexual abuse of males: The SAM model of theory and practice. New York: Routledge.

Steever, E. E., Follete, V. M., \& Naugle, A. E. (2001). The correlates of male adults' perceptions of their early sexual experiences. Journal of Traumatic Stress, 14(1), 189-204. doi:10.1023/A:1007852002481

Summit, R. C. (1983). The child sexual abuse accommodation syndrome. Child Abuse and Neglect, 7(2), 177-193. doi:10.1016/0145-2134(83)90070-4

Tobin, P., \& Kessner, S. L. (2002). Keeping kids safe: A child sexual abuse prevention manual. USA: Hunter House Publishers.

Jean Von Hohendorff is a Ph.D. candidate of the Graduate Program in Psychology at the Universidade Federal do Rio Grande do Sul.

Lucas Souza Costa holds a degree in Psychology from the Pontifícia Universidade Católica do Rio Grande do Sul.

Luisa Fernanda Habigzang is a Professor of the Graduate Program in Psychology at the Pontifícia Universidade Católica do Rio Grande do Sul.

Silvia Helena Koller is a Professor of the Instituto de Psicologia at the Universidade Federal do Rio Grande do Sul.

Received: Sep. 10, 2013

1st Revision: Mar. 10, 2014

Approved: Mar. 15, 2014
How to cite this article:

Hohendorff, J. V., Costa, L. S., Habigzang, L. F., \& Koller, S. H. (2014). Documentary analysis of cases of sexual violence against boys reported in Porto Alegre. Paidéia (Ribeirão Preto), 24(58), 187-195. doi: 10.1590/1982-43272458201406 


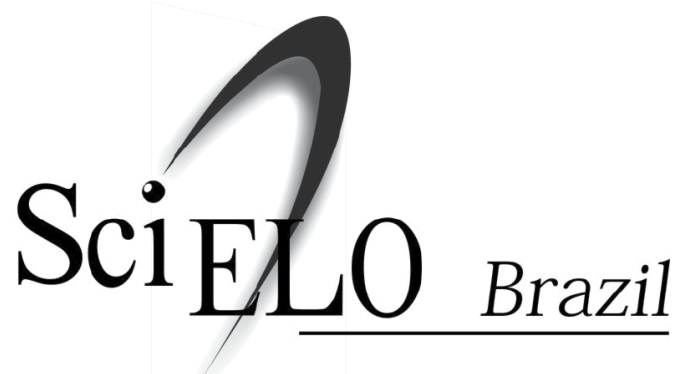
Paidéia (Ribeirão Preto) is a four-monthly publication available in full-text in the Scientific Electronic Library Online - SciELO.

The SciELO interface provides easy access to the tables of content and to the full-text articles.

The SciELO interface also provides the retrieval of articles by the author's name, the words from title, abstract and descriptors, in addition to providing bibliometric indicators and consultation indicators.

The articles are enriched with connections to the LILACS, MEDLINE and PubMed databases.

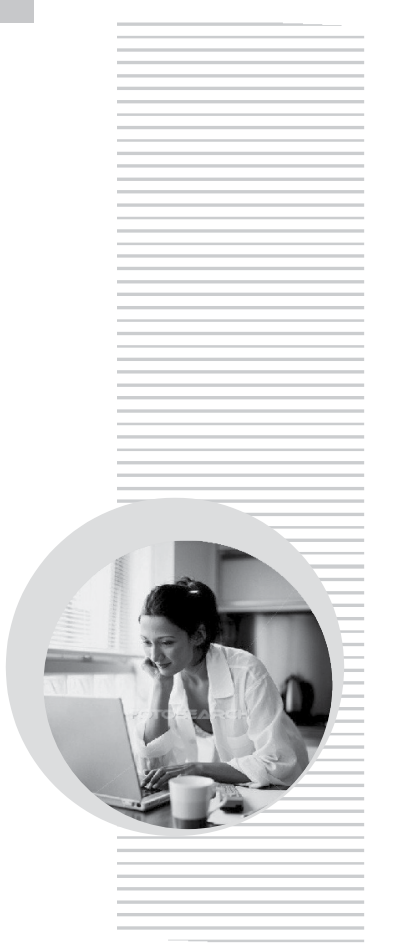

Paidéia (Ribeirão Preto) is a part of SciELO Brazil:

\section{www.scielo.br/paideia}

The SciELO interface provides access to a network of SciELO websites, gathering the major scientific journals of Latin America, Caribbean, Spain, Portugal and South Africa:

\section{www.scielo.org}

The electronic library is a project developed by the São Paulo Research Foundation (FAPESP), in partnership with the Latin American and Caribbean Center on Health Sciences Information (BIREME) and the National Council for Scientific and Technological Development (CNPq). 